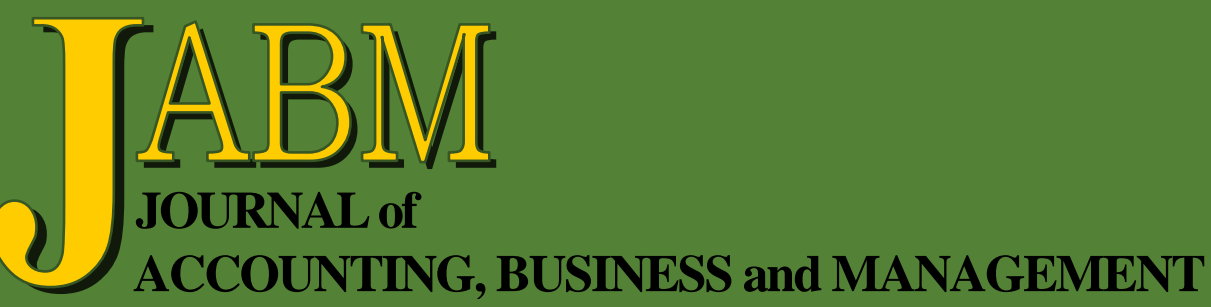

Audit Fee Premium for Industry Specialization: A Developed Country Perspective

Muhammad Shahin Miah

Socio-Demographics Characteristics on Investment Objectives of Individual Investors: Empirical Study in Indonesia

Nevi Danila, Zaiton Ali, Bunyamin and Marlinda D. K.

Dynamic Inflation and Economic Growth Nexus in Bangladesh

Md. Nezum Uddin

Voice of the Customer: Creating Client Centered Cultures in Accounting Firms for Retaining Clients and Increasing Profitability Leisa Gill, Vikkie McCarthy and David Grimmett

Rating the Credit Raters

A. Seetharaman, Nitin Patwa and Shriram Nagarajan 
Journal of Accounting, Business and Management (JABM) vol. 26 no. 2 (2019) 12-34

\title{
Socio-Demographics Characteristics on Investment Objectives of Individual Investors: Empirical Study in Indonesia
}

\author{
Nevi Danila* \\ Zaiton Ali† \\ Bunyamin $\ddagger$ \\ Marlinda D. K.S
}

\begin{abstract}
Every investor has a unique choice of investment based on customized needs and goals. Each investment has its characteristics. This study investigates the association between socio-demographic characteristics of individual investors and the objectives of the investments. Employing Pearson's chi-square test with 125 respondents from securities companies in Indonesia, we suggest that the decision of investors in investing their money depends on the association between sociodemographic characteristics and the characteristics of investments' goals. The results of this study can benefit both individual investors and securities firms. For individual investors, this study can be a guideline for them to make an investment decision by considering an investment objective that suits them the most. While for the securities companies, they can market their products to investors appropriately by looking into the demographic factors of the investors and indirectly know the investors' investments preference. More, the government needs to enhance the infrastructure of the financial sector in order to increase individuals participation in the sector.
\end{abstract}

Keywords: investment objectives, the safety of principal, capital growth, demographic factors, risk preference, individual investors.

\section{INTRODUCTION}

Different investors have different investments objectives and goals, for example, achieving a target profit for a long-term investment in the capital market (Sunariyah, 2011). The investment's decisions depend on many factors, such as risk and return from the investments, attitude of the investors, and knowledge of investors on the investment instruments. Currently, financial services institutions such as banks, insurance companies, finance companies (leasing), pension funds, capital markets, and pawnshops have introduced and issued various financial products and services. With varieties of available financial products, investors can participate and choose the products which are suitable for their investments needs. Research by Grable and Lytton (1998) and Watson and McNaughton (2007) suggest that socio-demographicfactors influence investment risk preferences. However, the investigation on factors that influence investment decision is few in Indonesia.

This research aims to study six investment objectives that affect investment decisions of investors, namely: preference towards the safety of principal, desire to earn

\footnotetext{
* Prince Sultan University, Riyadh, Kingdom of Saudi Arabia; and STIE Malangkuçeçwara, Indonesia. E-mail: ndanila@psu.edu.sa.

† Prince Sultan Univeresity, Riyadh, Kingdom of Saudi Arabia. E-mail: zali@psu.edu.sa.

* STIE Malangkuçeçwara, Indonesia. E-mail: benz@stie-mce.ac.id.

§STIE Malangkuçeçwara, Indonesia. E-mail: marlindakusuma25@gmail.com.
} 
a regular income, capital growth of the investment amount, to earnquick returns, tax benefit, and liquidity. In achieving the investment objective, investment risk preference is another factor, which needs to be considered.Several factors influence investment risk preferences, such as socio-demographic factors and financial literacy. The sociodemographic factors include gender, age, educational level, occupation, and marital status. Based on the above background, this research intends to examine the relationship (association) of demographic factors to the investment objectives by individual investors in securities firms in Indonesia.

\section{LITERATURE REVIEW}

This section discusses the six investments objectives and demographic factors, which affect investment risks preference by investors based on previous studies conducted by researchers across the globe.

The six investment objectives that will be applied in this study are as follows:

\subsection{Preference Towards the Safety of Principal}

According to Gitman and Joehnk (2005) investment is an activity form of deferred consumption in the present in a certain amount and for a specific time period in an efficient asset by investors, with the aim of earning a profit in the future at a certain level in accordance with the expected where the preference for the underlying security of investment is the investors make the choices (choices) of the products invested.

\subsection{Desire to Earn a Regular Income}

Darmadji and Fakhruddin (2012) state that fixed income (earn regular income) is derived from the shares of income (income stock) of an issuer that can pay a higher dividend than the average dividend paid in the previous year. Investment can work well not only as a retirement plan but also as a way to establish a fixed income. Invest in a desire to earn a regular income is a preferred strategy that could provide evidence favorable to the individual investor. Investors should be committed to monitoring its investments with caution in order to avoid significant losses.

\subsection{Capital Growth of the Investment Amount}

Capital growth is the result of a percentage of the increase in its capital compared with the amount of its capital before. Growth of the investment amount is the increase in the value of an asset or investment of time or can be shared in companies whose earnings are expected to grow at a rate above average relative to the market.

\subsection{Quick Returns}

To earn quick returns is an advantage in a given period. Fast payback (return) consisting of income and capital gains relative to investment and is usually quoted as a percentage. According to Corrado and Jordan (2000), the stock return is the profit earned from investors share ownership on its investments, consisting of dividends and capital gain or loss.

\subsection{Tax Benefit}

According to Law No. 36 the year 2008 on Value Added Tax (VAT), it is a tax regulation governing the imposition of income tax to entities and private persons who come into effect starting January 1, 2009. The amount of VAT charged $10 \%$ is final. However, there are tax benefits available to investors such as tax deduction, which is intended to reduce the burden on taxpayers and usually favor certain types of commercial activities. For example, the abolition of tax on dividend income, which was 
introduced by the Ministry of Finance in the era of Finance Minister Chatib Basri. Allowance of dividend tax benefits alone is intended to overcome the capital account deficit and to recall investors to invest in the stock market.

\subsection{Liquidity}

Stock liquidity is a measure of the number of transactions of stock in the capital market in a given period. The higher the frequency of the stock transactions, the higher the liquidity of the stock.

\subsection{Demographic Factors}

Based on previous researches, demographic factors have been identified to influence the risk preference on an investor. Among the factors that have been discussed include gender, age, level of education, and type of investors' occupations.

\subsection{Gender}

In general, men are being described as more confident compared to women and tend to be a risk-taker in investment activity. On the other hand, women are seen as a risk-averse investor. Barber and Oden (2001) found that the share turnover in men is generally higher than for women in a study conducted in the USA. While Lewellen et al. (1977) stated that there is a significant influence of gender on investment.

\subsection{Age}

Kiran and Rao (2005) suggest that the age factor strongly influences the risks taken in investing. They found that the respondents at the age group of 41-50 years tend to avoid risk (risk-averse). According to the World Health Organization (WHO) (year), age classifications are as follows:

1) Toddler period $=0-5$ years;

2) Childhood period $=6-11$ years;

3) Adolescence $=12-17$ years;

4) Adult period $=18-40$ years; and

5) Old age $=41-65$ years.

This study will apply the age classifications by WHO and will focus on two age groups, namely adulthood, and the old age.

\subsection{Level of education}

The level of education is the stages of education determined based on the level of development of learners, goals to be achieved, and the willingness developed. The level of education affects changes in attitudes and behavior of investors. A higher level of education will make it easier for a person or society to absorb information and implement it in everyday behavior and lifestyle. Formal education creates value for someone, especially in accepting the new terms. The education is an attempt to develop a personality and ability inside and outside the school and lasts a lifetime. In this study, the level of education used are:

1) High school education degree, and

2) Higher education degree.

\subsection{Work}

Barnewall (1987) suggests that certain occupational groups, such as corporate executives, lawyers, and doctors, prefer to avoid risk (risk-averse) in investing. A job is something to do to earn a living or livelihoods of people who are busy with activities, or daily work will have more time to obtain information. It is related to a person's income level. Thus it can be said that livelihoods can affect people's participation in 
development. This is because the work will affect the leisure time of a person to engage the nature of development. Work is divided into:

1) Employee,

2) Professional (doctor, lawyer),

3) Entrepreneur,

4) Retired,

5) Household, and

6) Others (college student).

\subsection{Marital Status}

According to Grable and Lytton (1998), married people have a sense of responsibility to the family. Therefore they are reluctant to take risks, which in contrast to single investors. Investors who are married with many family members usually put priority to the needs of their families rather than investment (Lutfi, 2010). It can be concluded that by having many family members, investors have to spend more money on living expenses, education, and others, which results in less money left for investment purposes.

Based on previous researches, this study intends to investigate demographic factors linkage to the investment objectives of individuals in Indonesia. The objectives of this study are:

1) To know and understand how individual investors use their limited financial resources to meet the needs of their financial goals, and

2) To identify the preferable investment objective among investors.

\section{HYPOTHESES}

There is a significant relationship between demographic factors and the investment objectives of individual investors.

Figure 1

Framework

\begin{tabular}{|c|c|}
\hline $\begin{array}{l}\text { Demographic Factors } \\
\text { 1. Age } \\
\text { 2. Gender } \\
\text { 3. Level of Education } \\
\text { 4. Work } \\
\text { 5. Marital Status }\end{array}$ & $\begin{array}{l}\text { Investment Objectives } \\
\text { 1. Preference Towards Safety of Principal } \\
\text { 2. Desire to Earn Regular Income } \\
\text { 3. Capital Growth of the Investment Amount } \\
\text { 4. Earn Quick Returns } \\
\text { 5. Tax Benefit } \\
\text { 6. Liquidity }\end{array}$ \\
\hline
\end{tabular}

\section{RESEARCH METHODOLOGY}

The method used was to study the investment objectives and critical factors for individual investors and also found the relationship of demographics against investment objectives by individual investors in securities companies in Malang. In this study, hypotheses, techniques, and tools are tested according to the applied ones on the subject under study. In the early stage, the research is based on a structured questionnaire to conduct in-depth studies on a variety of financial habits and preferences of individual investors. Respondents were asked questions about their financial planning and preferences. The target population for this study is the investors of securities companies in Indonesia. 


\subsection{Sampling Technique}

Respondents' targets include investors from various backgrounds of gender, age, degree, occupation, and marital status. Questionnaires were distributed to respondents, and at least a sample of 125 investors are anticipated.

\subsection{Data Collection}

Data collection involves the distribution and collection of hardcopy questionnaires, where respondents are requested to choose the most appropriate and relevant answers from the questions.

\subsection{Data Analysis Method}

Data analysis in this study involves descriptive analysis and statistical tests using weighted average and Pearson's chi-square methods.

\subsection{Weighted Average}

Weighted average is the average calculated by calculating the weights/weights for each data. Each weight/weight is a pair of each data. The weighted average can determine the preference for investment objectives and to know the first and last ranking.

\subsection{Pearson's Chi-Square}

The chi-square is a statistical test non-parametric (involves massive distribution population size is unknown) is quite often used in studies that make use of two variables, where the scale of the second data variable is nominal or to test the difference of two or more of the sample proportion. The chi-square test is applied to the case where it will be tested whether the frequency to be observed (observational data) to prove or there is a real or no correlation with the expected frequency.

In this research, chi-square is used to test the relationship (association) of demographic factors to the investment objectives by individual investors in securities firms that have been described previously. Hypothesis testing is done by looking at the value of its significance or value $X_{2}$ count. If the significant value is less than 0.05 (significance $<0.05$ ) or $X_{2}$ count $>X_{2}$ table, or $10 \%$ (significance $<0.1$ ) then the hypothesis proposed in this study is acceptable, and otherwise $\mathrm{H}_{0}$ is rejected and vice versa. The rules for making the decision are:

1) When the value of chi-square $\left(X_{2}\right) \geq$ table chi-square; zero hypothesis $\left(\mathrm{H}_{0}\right)$ is rejected and alternative hypothesis $\left(\mathrm{H}_{\mathrm{a}}\right)$ is accepted.

2) When the value of chi-square $\left(X_{2}\right)<$ table chi-square; null hypothesis $\left(\mathrm{H}_{0}\right)$ is accepted and alternative hypothesis $\left(\mathrm{H}_{\mathrm{a}}\right)$ is rejected.

\section{RESULTS AND DISCUSSIONS}

\subsection{Demographic Profile of Respondents}

The following chart depicts the age distribution among the respondents involved in the study. Approximately $40.8 \%$ of the respondents fall into the age group of 41 to 65 years old, while $59.2 \%$ is in the age group of 18 to 40 years old. 


\section{Chart 1}

\section{Age Group}

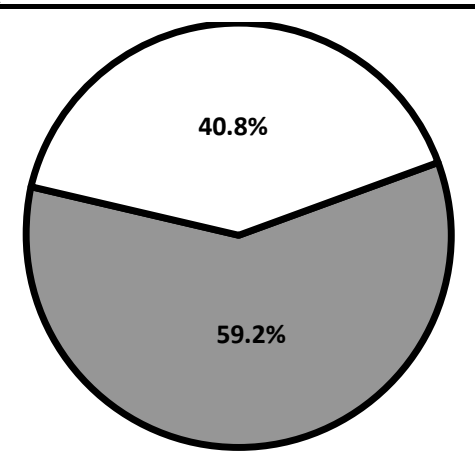

$\square 18$ to 40 years $\square 41$ to 52 years

In term of the gender of the respondents, results showthat male represents $51.2 \%$ and female is $48.8 \%$.

\section{Chart 2}

\section{Gender}

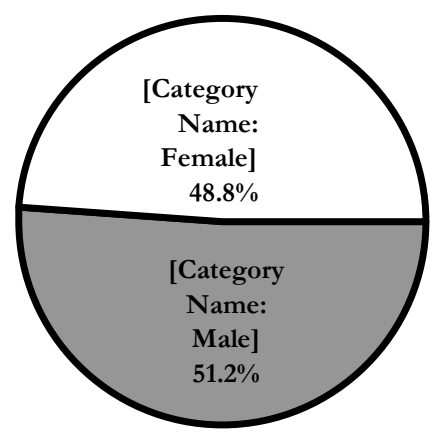

\subsection{Investment Objectives}

Based on the six investment objectives, the following table ranks the top to the least investment objectives preferences by the investors. "Safety of principle" is ranked number 1 , with the highest total of 526 responses. It proves that the safety of principal is an investment objective, which is favored by most individual investors. The tax benefits have the lowest response. This result showsthat the tax benefits of an investment are not in demand by an individual.Theoretically, investors aware that the investments made an addition to profit, but there is also a possibility of risk or loss. Besides, the safety of principal is also an alternative for investors to achieve long-term goals (Jorion, 2000). Investors do not favor tax benefits investment objective for several reasons, namely the indication of inconsistency in government regulation; the criteria requirements are challenging to meet, tax incentives are not the main factors affecting foreign investments, and the sluggish favorite industry in developing Asian countries. 
Table 1

Top and Least Ranked Investment Objective

\begin{tabular}{|c|c|c|c|c|c|c|c|c|}
\hline \multirow{2}{*}{ Rank Factor } & \multicolumn{6}{|c|}{ Number of Investors } & \multirow{2}{*}{ Total } & \\
\hline & 1 & 2 & 3 & 4 & 5 & 6 & & \\
\hline Safety of Principal & 76 & 2 & 2 & 1 & 5 & 39 & 125 & \\
\hline Regular Income & 3 & 38 & 42 & 28 & 10 & 4 & 125 & \\
\hline Capital Growth & 21 & 44 & 25 & 14 & 12 & 9 & 125 & \\
\hline Quick Returns & 27 & 25 & 28 & 19 & 11 & 15 & 125 & \\
\hline Tax Benefit & 1 & 12 & 16 & 21 & 50 & 25 & 125 & \\
\hline Liquidity & 2 & 2 & 14 & 40 & 36 & 31 & 125 & \\
\hline Weight Age & 6 & 5 & 4 & 3 & 2 & 1 & & \\
\hline Rank Factor & 1 & 2 & 3 & 4 & 5 & 6 & Total & Overall Rank \\
\hline Safety of Principal & 456 & 10 & 8 & 3 & 10 & 39 & 526 & 1 \\
\hline Regular Income & 18 & 190 & 168 & 84 & 20 & 4 & 484 & 4 \\
\hline Capital Growth & 126 & 220 & 100 & 42 & 24 & 9 & 521 & 2 \\
\hline Quick Returns & 162 & 125 & 112 & 76 & 22 & 15 & 512 & 3 \\
\hline Tax Benefit & 6 & 60 & 64 & 84 & 100 & 25 & 339 & 6 \\
\hline Liquidity & 12 & 10 & 56 & 160 & 72 & 31 & 341 & 5 \\
\hline
\end{tabular}

Source: SPSS output processed results.

\subsection{Gender and Objectives of Investment}

\section{Table 2}

Gender and Safety of Principal

\begin{tabular}{|c|c|c|c|c|c|c|c|c|}
\hline \multirow{2}{*}{$\begin{array}{c}\text { Investment } \\
\text { Objective }\end{array}$} & \multirow{2}{*}{ Gender } & \multicolumn{6}{|c|}{ Rank } & \multirow{2}{*}{ Total } \\
\hline & & 1 & 2 & 3 & 4 & 5 & 6 & \\
\hline \multirow{6}{*}{$\begin{array}{l}\text { Safety of } \\
\text { Principal }\end{array}$} & Men & 24 & 1 & 1 & 1 & 5 & 29 & $\overline{61}$ \\
\hline & Percent & $39.3 \%$ & $1.6 \%$ & $1.7 \%$ & $1.7 \%$ & $8.2 \%$ & $47.5 \%$ & $100.0 \%$ \\
\hline & Female & 52 & 1 & 1 & 0 & 0 & 10 & 64 \\
\hline & Percent & $81.3 \%$ & $1.6 \%$ & $1.6 \%$ & $0.0 \%$ & $0.0 \%$ & $15.6 \%$ & $100.0 \%$ \\
\hline & Total & 76 & 2 & 2 & 1 & 5 & 39 & 125 \\
\hline & Percent & $60.8 \%$ & $1.6 \%$ & $1.6 \%$ & $0.8 \%$ & $4.0 \%$ & $31.2 \%$ & $100.0 \%$ \\
\hline
\end{tabular}

Source: SPSS output processed results.

Further analysis of demographic figure and investment objective shows that the most significant percentage $(47.5 \%)$ of men put "safety of principal" as the lowest rank. This result is, in contrast, compares to female's ranking on "safety of principal," as the majority of female $(81.3 \%)$ choose "safety of principal" as a priority for investment objective. This indicates that women are more cautious (conservative) in making investments. This result is supported by findings by Mittal and Vyas (2010), which state that women are more careful to minimize errors in investing, while men tend to make decisions quickly and at risk.

Table 3

Gender and Regular Income

\begin{tabular}{|c|c|c|c|c|c|c|c|c|}
\hline \multirow{2}{*}{$\begin{array}{c}\text { Investment } \\
\text { Objective }\end{array}$} & \multirow{2}{*}{ Gender } & \multicolumn{6}{|c|}{ Rank } & \multirow{2}{*}{ Total } \\
\hline & & 1 & 2 & 3 & 4 & 5 & 6 & \\
\hline \multirow{6}{*}{$\begin{array}{l}\text { Regular } \\
\text { Income }\end{array}$} & Men & 2 & 19 & 22 & 12 & 4 & 2 & 61 \\
\hline & Percent & $3.3 \%$ & $31.1 \%$ & $36.1 \%$ & $19.7 \%$ & $6.6 \%$ & $3.2 \%$ & $100.0 \%$ \\
\hline & Female & 1 & 19 & 20 & 16 & 6 & 2 & 64 \\
\hline & Percent & $1.6 \%$ & $29.7 \%$ & $31.3 \%$ & $25.0 \%$ & $9.4 \%$ & $3.1 \%$ & $100.0 \%$ \\
\hline & Total & 3 & 38 & 42 & 28 & 10 & 4 & 125 \\
\hline & Percent & $2.4 \%$ & $30.4 \%$ & $33.6 \%$ & $22.4 \%$ & $8.0 \%$ & $3.2 \%$ & $100.0 \%$ \\
\hline
\end{tabular}

Source: SPSS output processed results. 
Table 3 shows that both male and female rank a regular income as the third rank. It implies that the investment in the financial sector does not provide their primary source of income. The income from the investment is as an additional income. Komarudin (2004) suggests that wise investors think about how to improve their level of income from time to time with preserving the current level of regular income.

\section{Table 4}

\section{Gender and Capital Growth}

\begin{tabular}{|c|c|c|c|c|c|c|c|c|}
\hline \multirow{2}{*}{$\begin{array}{l}\text { Investment } \\
\text { Objective }\end{array}$} & \multirow{2}{*}{ Gender } & \multicolumn{6}{|c|}{ Rank } & \multirow{2}{*}{ Total } \\
\hline & & 1 & 2 & 3 & 4 & 5 & 6 & \\
\hline \multirow{6}{*}{$\begin{array}{l}\text { Capital } \\
\text { Growth }\end{array}$} & Men & 14 & 25 & 6 & 4 & 7 & 5 & 61 \\
\hline & Percent & $23.0 \%$ & $41.0 \%$ & $9.8 \%$ & $6.5 \%$ & $11.5 \%$ & $8.2 \%$ & $100.0 \%$ \\
\hline & Female & 7 & 19 & 19 & 10 & 5 & 4 & 64 \\
\hline & Percent & $10.9 \%$ & $29.7 \%$ & $29.7 \%$ & $15,6 \%$ & $7.8 \%$ & $6.3 \%$ & $100.0 \%$ \\
\hline & Total & 21 & 44 & 25 & 14 & 12 & 9 & 125 \\
\hline & Percent & $16.8 \%$ & $35.2 \%$ & $20.0 \%$ & $11.2 \%$ & $9.6 \%$ & $7.2 \%$ & $100.0 \%$ \\
\hline
\end{tabular}

Source: SPSS output processed results.

Table 4 indicates that both male and female have the same preference of capital growth as an investment's objective. They rank the objective as the second rank. It implies that both genders consider investing for a long-term period. Even though they are not keen on receiving a regular income, but they want their investment growing steadily. An upward trend of capital growth is an essential factor for investors since it indicates that the firm has a good and steady growth of profits.

\section{Table 5}

Gender and Quick Returns

\begin{tabular}{|c|c|c|c|c|c|c|c|c|}
\hline \multirow{2}{*}{$\begin{array}{c}\text { Investment } \\
\text { Objective }\end{array}$} & \multirow{2}{*}{ Gender } & \multicolumn{6}{|c|}{ Rank } & \multirow{2}{*}{ Total } \\
\hline & & 1 & 2 & 3 & 4 & 5 & 6 & \\
\hline \multirow{6}{*}{$\begin{array}{l}\text { Quick } \\
\text { Returns }\end{array}$} & Men & 20 & 14 & 14 & 1 & 2 & 10 & 61 \\
\hline & Percent & $32.8 \%$ & $23 \%$ & $23 \%$ & $11.6 \%$ & $3.3 \%$ & $6.3 \%$ & $100.0 \%$ \\
\hline & Female & 7 & 11 & 14 & 18 & 9 & 5 & 64 \\
\hline & Percent & $10.9 \%$ & $17.2 \%$ & $21.9 \%$ & $28.1 \%$ & $14.1 \%$ & $7.8 \%$ & $100.0 \%$ \\
\hline & Total & 27 & 25 & 28 & 19 & 11 & 15 & 125 \\
\hline & Percent & $21.6 \%$ & $20.0 \%$ & $22.4 \%$ & $15.2 \%$ & $8.8 \%$ & $12.0 \%$ & $100.0 \%$ \\
\hline
\end{tabular}

Source: SPSS output processed results

Table 5 indicates that there is a different rank between male and female. Male investors set a quick return objective as a first rank, while female investors rank the objective as a fourth rank. It infers that male investors have a high intensity of trading in the market. As suggested by Barber and Odean (2001), they stated that male investors are more risk-taker and frequently trade in the market. They expect to get a higher return for receiving higher risk. In contrast, female investors are more conservative in investing their money. Safety of principal is the most concern of female investors. Consequently, they do not prioritize the quick return from their investment.

Table 6 shows that both of the genders do not consider tax benefit as a priority investment objective. They rank the objective as the fifth rank, and almost the last rank. The amount of tax does not give a distinction of benefit for their income. 
Table 6

Gender and Tax Benefit

\begin{tabular}{|c|c|c|c|c|c|c|c|c|}
\hline \multirow{2}{*}{$\begin{array}{l}\text { Investment } \\
\text { Objective }\end{array}$} & \multirow{2}{*}{ Gender } & \multicolumn{6}{|c|}{ Rank } & \multirow{2}{*}{ Total } \\
\hline & & 1 & 2 & 3 & 4 & 5 & 6 & \\
\hline \multirow{6}{*}{$\begin{array}{c}\text { Tax } \\
\text { Benefit }\end{array}$} & Men & 0 & 2 & 11 & 14 & 27 & 7 & 61 \\
\hline & Percent & $0.0 \%$ & $3.3 \%$ & $18.0 \%$ & $23.0 \%$ & $44.3 \%$ & $11.5 \%$ & $100.0 \%$ \\
\hline & Female & 1 & 10 & 5 & 7 & 23 & 18 & 64 \\
\hline & Percent & $1.6 \%$ & $15.6 \%$ & $7.8 \%$ & $10.9 \%$ & $35.9 \%$ & $28.1 \%$ & $100.0 \%$ \\
\hline & Total & 1 & 12 & 16 & 21 & 50 & 25 & 125 \\
\hline & Percent & $0.8 \%$ & $9.6 \%$ & $12.8 \%$ & $16.8 \%$ & $40.0 \%$ & $20.0 \%$ & $100.0 \%$ \\
\hline \multirow{3}{*}{\multicolumn{9}{|c|}{$\begin{array}{l}\text { Source: SPSS output processed res } \\
\text { Table } 7 \\
\text { Gender and Liquidity }\end{array}$}} \\
\hline & & & & & & & & \\
\hline & & & & & & & & \\
\hline \multirow{2}{*}{$\begin{array}{c}\text { Investment } \\
\text { Objective }\end{array}$} & \multirow{2}{*}{ Gender } & \multicolumn{6}{|c|}{ Rank } & \multirow{2}{*}{ Total } \\
\hline & & 1 & 2 & 3 & 4 & 5 & 6 & \\
\hline \multirow{6}{*}{ Liquidity } & Men & 1 & 0 & 7 & 28 & 16 & 9 & 61 \\
\hline & Percent & $1.6 \%$ & $0.0 \%$ & $11.5 \%$ & $45.9 \%$ & $26.2 \%$ & $14.8 \%$ & $100.0 \%$ \\
\hline & Female & 1 & 2 & 7 & 12 & 20 & 22 & 64 \\
\hline & Percent & $1.6 \%$ & $3.1 \%$ & $10.9 \%$ & $18.8 \%$ & $31.3 \%$ & $34.4 \%$ & $100.0 \%$ \\
\hline & Total & 2 & 2 & 14 & 40 & 36 & 31 & 125 \\
\hline & Percent & $1.6 \%$ & $1.6 \%$ & $11.2 \%$ & $32.0 \%$ & $28.8 \%$ & $24.8 \%$ & $100.0 \%$ \\
\hline
\end{tabular}

Source: SPSS output processed results.

Table 7 indicates that male investors set a higher rank than female investors do, i.e., fourth and fifth ranks consecutively. It confirms the previous result that male investors expect quick returns. This objective is hand in hand with a liquidity objective. The investors keep monitoring the trading and have a higher self-confident to decide to buy or sell the stocks. Thus, the liquidity of the market is one of the crucial factors for them. While female investors tend to be more careful in deciding to buy or selling stocks. Barber and Odean (2001) stated that male investors are more risk taker and are overconfidence than their counterpart.

Table 8

Chi-Square Test: Gender and Objectives of Investment

\begin{tabular}{lccc}
\hline \multicolumn{1}{c}{ Objective } & Value & Df & Asymp. Sig (2-sided) \\
\hline Safety of Principal & $25.515^{\mathrm{a}}$ & 5 & .000 \\
Regular Income & $1.329^{\mathrm{a}}$ & 5 & .932 \\
Capital Growth & $12.863^{\mathrm{a}}$ & 5 & .250 \\
Quick Returns & $27.895^{\mathrm{a}}$ & 5 & .000 \\
Tax Benefit & $16.014^{\mathrm{a}}$ & 5 & .007 \\
Liquidity & $14.232^{\mathrm{a}}$ & 5 & .014 \\
\hline
\end{tabular}

Source: SPSS output processed results.

Based on the above table, it can be seen that the demographic factor "gender" relates significantly to the safety of principal investment objective, quick returns, tax benefits, and liquidity. So gender has differences in the investment objectives, especially the safety of principal, quick returns, tax benefits, and liquidity. This is because women tend to be more cautious in investing than men; women are more concerned about security in investment (Cooper \& Schindler, 2006). 


\subsection{Age and objectives of investments}

\section{Table 9}

Age and Safety Principal

\begin{tabular}{clccccccc}
\hline \multirow{2}{*}{\begin{tabular}{c} 
Investment $\begin{array}{c}\text { Rank } \\
\text { Objective }\end{array}$ \\
\cline { 2 - 8 }
\end{tabular}} & \multicolumn{1}{c}{ Age } & $\mathbf{1}$ & $\mathbf{2}$ & $\mathbf{3}$ & $\mathbf{4}$ & $\mathbf{5}$ & $\mathbf{6}$ & \multirow{2}{*}{ Total } \\
\hline \multirow{3}{*}{$\begin{array}{c}\text { Safety of } \\
\text { Principal }\end{array}$} & $18-40$ Years & 40 & 1 & 1 & 0 & 1 & 35 & 78 \\
& Percent & $51.3 \%$ & $1.3 \%$ & $1.3 \%$ & $0.0 \%$ & $1.3 \%$ & $44.9 \%$ & $100.0 \%$ \\
\cline { 2 - 8 } & $41-65$ Years & 36 & 1 & 1 & 1 & 4 & 4 & 47 \\
& Percent & $76.6 \%$ & $2.1 \%$ & $2.1 \%$ & 2.1 & $8.5 \%$ & $8.5 \%$ & $100.0 \%$ \\
\cline { 2 - 8 } & Total & 76 & 2 & 2 & 1 & 5 & 39 & 125 \\
& Percent & $60.8 \%$ & $1.6 \%$ & $1.6 \%$ & $0.8 \%$ & $4.0 \%$ & $31.2 \%$ & $100.0 \%$ \\
\hline
\end{tabular}

Source: SPSS output processed results.

The above table shows that the most significant percentage $(51.3 \%)$ for the age group 18-40 years and 76.6\% of investors aged $41-65$ years, choose "safety of principal" as the first rank. The younger age group is expected to exhibit such result as in making investment decisions as they are very cautious of "safety of principal" due to lesser investments' experience. However, the elder age group has a similar result, even though the elder has much more investments' experience. Christanti and Mahastanti (2011) supported the finding. The authors state that mature investors (41-65 years old) consider prioritizing the safety of principle as an investment objective even though they have much experience.

\section{Table 10}

Age and Regular Income

\begin{tabular}{|c|c|c|c|c|c|c|c|c|}
\hline \multirow{2}{*}{$\begin{array}{c}\text { Investment } \\
\text { Objective }\end{array}$} & \multirow{2}{*}{ Age } & \multicolumn{6}{|c|}{ Rank } & \multirow{2}{*}{ Total } \\
\hline & & 1 & 2 & 3 & 4 & 5 & 6 & \\
\hline \multirow{6}{*}{$\begin{array}{l}\text { Regular } \\
\text { Income }\end{array}$} & $18-40$ Years & 2 & 21 & 28 & 18 & 7 & 2 & 78 \\
\hline & Percent & $2,6 \%$ & $26,9 \%$ & $35,9 \%$ & $23,1 \%$ & $9,0 \%$ & 2,6 & $100,0 \%$ \\
\hline & 41-65 Years & 1 & 17 & 14 & 10 & 3 & 2 & 47 \\
\hline & Percent & $2,1 \%$ & $36,2 \%$ & $29,8 \%$ & $21,3 \%$ & $6,4 \%$ & $4,3 \%$ & $100,0 \%$ \\
\hline & Total & 3 & 38 & 42 & 28 & 10 & 4 & 125 \\
\hline & Percent & $2,4 \%$ & $30,4 \%$ & $33,6 \%$ & $22,4 \%$ & $8,0 \%$ & $3,2 \%$ & $100,0 \%$ \\
\hline
\end{tabular}

Source: SPSS output processed results.

Table 10 shows that $18-40$ years old investors place the regular income objective as third place, while 41-65 years old investors place the objective as the second rank. It infers that the younger group of investors have more variety of income resources. Furthermore, the older group of investors tend to be risk-averse investors; they need more stable income resources. However, younger group of investors are risk seeker investors. They are more comfortable in dealing with the risk.

\section{Table 11}

Age and Capital Growth

\begin{tabular}{clccccccc}
\hline \multirow{2}{*}{$\begin{array}{c}\text { Investment } \\
\text { Objective }\end{array}$} & \multicolumn{1}{c}{ Age } & $\mathbf{1}$ & $\mathbf{2}$ & $\mathbf{3}$ & $\mathbf{4}$ & $\mathbf{5}$ & $\mathbf{6}$ & \multirow{2}{*}{ Total } \\
\cline { 2 - 8 } & $18-40$ Years & 16 & 28 & 17 & 10 & 5 & 2 & 78 \\
& Percent & $20,5 \%$ & $35,9 \%$ & $21,8 \%$ & $12,8 \%$ & $6,4 \%$ & $2,6 \%$ & $100,0 \%$ \\
\cline { 2 - 8 } Capital & $41-65$ Years & 5 & 16 & 8 & 4 & 7 & 12 & 47 \\
Growth & Percent & $10,6 \%$ & $34,0 \%$ & $17,0 \%$ & $8,5 \%$ & $14,9 \%$ & $9,6 \%$ & $100,0 \%$ \\
\cline { 2 - 8 } & Total & 21 & 44 & 25 & 14 & 12 & 9 & 125 \\
& Percent & $16,8 \%$ & $35,2 \%$ & $20,0 \%$ & $11,2 \%$ & $9,6 \%$ & $7,2 \%$ & $100,0 \%$ \\
\hline
\end{tabular}

Source: SPSS output processed results. 
Both age groups have the same level of priority for capital growth as an investment objective. Capital growth is important for younger investors since they have more time to accumulate their wealth. Furthermore, the older investors need capital growth of their investment to prepare their retirement period.

\section{Table 12}

\section{Age and Quick Return}

\begin{tabular}{clccccccc}
\hline \multirow{2}{*}{$\begin{array}{c}\text { Investment } \\
\text { Objective }\end{array}$} & \multicolumn{1}{c}{ Age } & $\mathbf{1}$ & $\mathbf{2}$ & $\mathbf{3}$ & $\mathbf{4}$ & $\mathbf{5}$ & $\mathbf{6}$ & \multirow{2}{*}{ Total } \\
\cline { 2 - 8 } & $18-40$ Years & 22 & 17 & 15 & 12 & 6 & 6 & 78 \\
& Percent & $28,2 \%$ & $21,8 \%$ & $19,2 \%$ & $15,4 \%$ & $7,7 \%$ & $7,7 \%$ & $100,0 \%$ \\
\cline { 2 - 8 } Quick & $41-65$ Years & 5 & 8 & 13 & 7 & 5 & 9 & 47 \\
Returns & Percent & $10,6 \%$ & $17,0 \%$ & $27,7 \%$ & $14,9 \%$ & $10,6 \%$ & $19,1 \%$ & $100,0 \%$ \\
\cline { 2 - 8 } & Total & 27 & 25 & 28 & 19 & 11 & 15 & 125 \\
& Percent & $21,6 \%$ & $20,0 \%$ & $22,4 \%$ & $15,2 \%$ & $8,8 \%$ & $12,0 \%$ & $100,0 \%$ \\
\hline
\end{tabular}

Source: SPSS output processed results.

As expected, the younger group of investors place quick returns objective as the first rank. It is consistent with the fact that the younger group of investors tend to be risk seeker. In contrary, the older group of investors rank this objective at $3^{\text {rd }}$ level. It indicates the older group have more consideration in the market trading as they need to protect their wealth. Christanti dan Mahastanti (2011) argued that older people have a more conservative attitude in investing their money in the financial market.

Table 13

Age and Tax Benefit

\begin{tabular}{clccccccc}
\hline \multirow{2}{*}{$\begin{array}{c}\text { Investment } \\
\text { Objective }\end{array}$} & \multicolumn{1}{c}{ Age } & $\mathbf{1}$ & $\mathbf{2}$ & $\mathbf{3}$ & $\mathbf{4}$ & $\mathbf{5}$ & $\mathbf{6}$ & Total \\
\cline { 2 - 8 } & $18-40$ Years & 0 & 7 & 8 & 14 & 32 & 17 & 78 \\
& Percent & $0,0 \%$ & $9,0 \%$ & $10,3 \%$ & $17,9 \%$ & $41,0 \%$ & $21,8 \%$ & $100,0 \%$ \\
\cline { 2 - 9 } Tax & $41-65$ Years & 1 & 5 & 8 & 7 & 18 & 8 & 47 \\
Benefit & Percent & $2,1 \%$ & $10,6 \%$ & $17,0 \%$ & $14,9 \%$ & $38,3 \%$ & 17,0 & $100,0 \%$ \\
\cline { 2 - 8 } & Total & 1 & 12 & 16 & 21 & 50 & 25 & 125 \\
& Percent & $0,8 \%$ & $9,6 \%$ & $12,8 \%$ & $16,8 \%$ & $40,0 \%$ & $20,0 \%$ & $100,0 \%$ \\
\hline
\end{tabular}

Source: SPSS output processed results.

Again, both age groups do not consider a tax benefit as an essential investment objective. This finding is consistent with the previous result, i.e., a tax benefit does not give them a free benefit for increasing their income. They assume that $10 \%$ of personal tax is high enough to reduce their wealth.

Table 14

Age and Liquidity

\begin{tabular}{|c|c|c|c|c|c|c|c|c|}
\hline \multirow{2}{*}{$\begin{array}{c}\text { Investment } \\
\text { Objective }\end{array}$} & \multirow{2}{*}{ Age } & \multicolumn{6}{|c|}{ Rank } & \multirow{2}{*}{ Total } \\
\hline & & 1 & 2 & 3 & 4 & 5 & 6 & \\
\hline \multirow{6}{*}{ Liquidity } & 18-40 Years & 2 & 2 & 10 & 23 & 26 & 15 & 78 \\
\hline & Percent & $2,6 \%$ & $2,6 \%$ & $12,8 \%$ & $29,5 \%$ & $33,3 \%$ & $19,2 \%$ & $100,0 \%$ \\
\hline & 41-65 Years & 0 & 0 & 4 & 17 & 10 & 16 & 47 \\
\hline & Percent & $0,0 \%$ & $0,0 \%$ & $8,5 \%$ & $36,2 \%$ & $21,3 \%$ & $34,0 \%$ & $100,0 \%$ \\
\hline & Total & 2 & 2 & 14 & 40 & 36 & 31 & 125 \\
\hline & Percent & $1,6 \%$ & $1,6 \%$ & $11,2 \%$ & $32,0 \%$ & $28,8 \%$ & $24,8 \%$ & $100,0 \%$ \\
\hline
\end{tabular}

Source: SPSS output processed results. 
Both age groups do not place liquidity as a crucial objective. However, the younger group of investors rank liquidity at a higher rank than the older one. This notion is in line with Barber and Odean (2001) finding. The author suggested that the younger group of investors choose higher volatile stocks. As mentioned above, younger people are more comfortable with the risk for the sake of higher returns.

Table 15

Chi-Square Test: Age and Objectives of Investment

\begin{tabular}{lccc}
\hline \multicolumn{1}{c}{ Objective } & Value & Df & Asymp. Sig (2-sided) \\
\hline Safety of Principal & $21.272^{\mathrm{a}}$ & 5 & .001 \\
Regular Income & $1.725^{\mathrm{a}}$ & 5 & .886 \\
Capital Growth & $10.942^{\mathrm{a}}$ & 5 & .053 \\
Quick Returns & $8.956^{\mathrm{a}}$ & 5 & .111 \\
Tax Benefit & $3.344^{\mathrm{a}}$ & 5 & .647 \\
Liquidity & $7.381^{\mathrm{a}}$ & 5 & .194 \\
\hline
\end{tabular}

Source: SPSS output processed results.

Based on the above table, it can be seen that the demographic factor "age" significantly related to the investment objectives of safety of principal and capital growth, this is because investors with age 18-40 years tend to have more volatile stock portfolio, so investors do not like the state of the remains and more are likely to change (Barber \& Odean, 2001). Besides, investors aged 18-40 years are braver in taking risks and investing decisions compared to investors aged 41-65 years. While the demographic factors of age do not have a significant relationship to the purpose of regular investment income, quick returns, tax benefits, and liquidity. This is because regardless of the age of investors, they still have the same consideration of the investment objectives. The results are consistent with previous studies conducted by Zinkhan and Karande (1990).

\subsection{Level Education and Objective of the Investment}

\section{Table16}

Level of Education and Safety of Principal

\begin{tabular}{|c|c|c|c|c|c|c|c|c|}
\hline \multirow{2}{*}{$\begin{array}{c}\text { Investment } \\
\text { Objective }\end{array}$} & \multirow{2}{*}{$\begin{array}{c}\text { Level of } \\
\text { Education }\end{array}$} & \multicolumn{6}{|c|}{ Rank } & \multirow{2}{*}{ Total } \\
\hline & & 1 & 2 & 3 & 4 & 5 & 6 & \\
\hline \multirow{6}{*}{$\begin{array}{l}\text { Safety of } \\
\text { Principal }\end{array}$} & High School & 9 & 2 & 2 & 1 & 5 & 21 & 40 \\
\hline & Percent & $22.5 \%$ & $5.0 \%$ & $5.0 \%$ & $2.5 \%$ & $12.5 \%$ & $52.5 \%$ & $100.0 \%$ \\
\hline & Higher & 67 & 0 & 0 & 0 & 0 & 18 & 85 \\
\hline & Education & & & & & & & \\
\hline & Percent & $18.8 \%$ & $0.0 \%$ & $0.0 \%$ & $0.0 \%$ & $0.0 \%$ & $21.2 \%$ & $100.0 \%$ \\
\hline & $\begin{array}{l}\text { Total } \\
\text { Percent }\end{array}$ & $\begin{array}{c}76 \\
60.8 \%\end{array}$ & $\begin{array}{c}2 \\
1.6 \%\end{array}$ & $\begin{array}{c}2 \\
16 \%\end{array}$ & $\begin{array}{c}1 \\
0.8 \%\end{array}$ & $\begin{array}{c}5 \\
40^{\circ}\end{array}$ & $\begin{array}{c}39 \\
31.2 \%\end{array}$ & $\begin{array}{c}125 \\
100.0 \%\end{array}$ \\
\hline
\end{tabular}

Source: SPSS output processed results.

From the above table, the most significant percentage $(52.5 \%)$ high school degree or equivalent investors choose safety of principal as the lowest ranking. This result is in contrast to investors who hold Bachelor/Master degrees as the majority of them $(78.8 \%)$ make "safety of principal" a priority in investment objectives. This shows that the investor holds a Bachelor Degree or postgraduate education has a level of control on how his ability to understand the safety of principal as a destination for his investment than an investor who holds a high school or equivalent. The above analysis is strengthened by Bhandari and Deaves (2006) who stated that the level of education 
also influences investor tolerance to safety of principal - the higher the level of education, the higher the tolerance to safety of principal as the investment objective.

Table 17

Level of Education and Regular Income

\begin{tabular}{|c|c|c|c|c|c|c|c|c|}
\hline \multirow{2}{*}{$\begin{array}{c}\text { Investment } \\
\text { Objective }\end{array}$} & \multirow{2}{*}{$\begin{array}{c}\text { Level of } \\
\text { Education }\end{array}$} & \multicolumn{6}{|c|}{ Rank } & \multirow{2}{*}{ Total } \\
\hline & & 1 & 2 & 3 & 4 & 5 & 6 & \\
\hline \multirow{6}{*}{$\begin{array}{l}\text { Regular } \\
\text { Income }\end{array}$} & High School & 3 & 11 & 16 & 9 & 0 & 1 & 40 \\
\hline & Percent & $7.5 \%$ & $27.5 \%$ & $40.0 \%$ & $22.5 \%$ & $0.0 \%$ & $2.5 \%$ & $100.0 \%$ \\
\hline & Higher & 0 & 27 & 26 & 19 & 10 & 3 & 85 \\
\hline & $\begin{array}{l}\text { Education } \\
\text { Percent }\end{array}$ & $0.0 \%$ & $31.8 \%$ & $30.6 \%$ & $22.4 \%$ & $11.8 \%$ & $3.5 \%$ & $100.0 \%$ \\
\hline & Total & 3 & 38 & 42 & 28 & 10 & 4 & 125 \\
\hline & Percent & $2.4 \%$ & $30.4 \%$ & $33.6 \%$ & $22.4 \%$ & $8.0 \%$ & $3.2 \%$ & $100.0 \%$ \\
\hline
\end{tabular}

Source: SPSS output processed results.

Table 17 indicates that lower education level ranks the regular income as the third rank. It is surprising since the lower level of education people have less income than the higher level of education people. It may be a lack of knowledge of financial products. They tend to have herding behavior, following other people action on buying and selling, instead of based on their knowledge. On the other hand, the higher education level people put a regular income as the secondary importance of investment objective. The higher education group is more knowledgeable in financial products and have technical analysis skill. This finding is in-line with Lutfi (2010). The author argued that higher education level investors have a regular income as a priority goal in the financial sector.

\section{Table 18}

\section{Level of Education and Capital Growth}

\begin{tabular}{|c|c|c|c|c|c|c|c|c|}
\hline \multirow{2}{*}{$\begin{array}{c}\text { Investment } \\
\text { Objective }\end{array}$} & \multirow{2}{*}{$\begin{array}{c}\text { Level of } \\
\text { Education }\end{array}$} & \multicolumn{6}{|c|}{ Rank } & \multirow{2}{*}{ Total } \\
\hline & & 1 & 2 & 3 & 4 & 5 & 6 & \\
\hline \multirow{7}{*}{$\begin{array}{l}\text { Capital } \\
\text { Growth }\end{array}$} & High School & 14 & 15 & 5 & 3 & 2 & 1 & 40 \\
\hline & Percent & $35.0 \%$ & $37.5 \%$ & $12.5 \%$ & $7.5 \%$ & $5.0 \%$ & $2.5 \%$ & $100.0 \%$ \\
\hline & Higher & 7 & 29 & 20 & 11 & 10 & 8 & 85 \\
\hline & Education & & & & & & & \\
\hline & Percent & $8.2 \%$ & $34.1 \%$ & $23.5 \%$ & $12.9 \%$ & $11.8 \%$ & $9.4 \%$ & $100.0 \%$ \\
\hline & Total & 21 & 44 & 25 & 14 & 12 & 9 & 125 \\
\hline & Percent & $16.8 \%$ & $35.2 \%$ & $20.0 \%$ & $11.2 \%$ & $9.6 \%$ & $7.2 \%$ & $100.0 \%$ \\
\hline
\end{tabular}

Source: SPSS output processed results.

Both high school and higher education level investors put capital growth as the critical investment objective, i.e. the second rank. They acknowledge that the capital market provides aggressive stocks, which have fast growth. According to Nguyen and Schübler (2012), level of education reduces a self-attribution bias, which increases the investors' capability in managing their investment.

Insert Table 19 here.

Table 19 shows that the high school level of education ranks quick returns as first rank. The outcome is not surprising. The high school level of education investors has less knowledge than its counterpart in the capital market. It leads it to be more comfortable with the risk, i.e. they tend to be risk-taker. One of the attributes of risktaker is focusing on the quick return of their investments. On the other hand, the higher education level of investors tends to be more risk-averse. They are more knowledgeable in the capital market, which leads to being more careful in choosing the 
stocks. They consider many aspects before buying or selling stocks. That is why the higher education level of investors put quick returns as the third priority.

Table 19

Level of Education and Quick Returns

\begin{tabular}{clcccccccc}
\hline Investment & $\begin{array}{c}\text { Level of } \\
\text { Objective }\end{array}$ & Education & $\mathbf{1}$ & $\mathbf{2}$ & $\mathbf{3}$ & $\mathbf{4}$ & $\mathbf{5}$ & $\mathbf{6}$ & \multirow{2}{*}{ Total } \\
\cline { 2 - 9 } & High School & 16 & 8 & 8 & 2 & 1 & 5 & 40 \\
& Percent & $40.0 \%$ & $20.0 \%$ & $20.0 \%$ & $5.0 \%$ & $2.5 \%$ & $12.5 \%$ & $100.0 \%$ \\
\cline { 2 - 9 } Quick & Higher & 11 & 17 & 20 & 17 & 10 & 10 & 85 \\
Returns & $\begin{array}{l}\text { Education } \\
\text { Percent }\end{array}$ & $12.9 \%$ & $20.0 \%$ & $23.5 \%$ & $20.0 \%$ & $11.8 \%$ & $11.8 \%$ & $100.0 \%$ \\
\cline { 2 - 8 } & Total & 27 & 25 & 28 & 19 & 11 & 15 & 125 \\
& Percent & $21.6 \%$ & $20.0 \%$ & $22.4 \%$ & $15.2 \%$ & $8.8 \%$ & $12.0 \%$ & $100.0 \%$ \\
\hline
\end{tabular}

Source: SPSS output processed results.

Table 20

Level of Education and Tax Benefit

\begin{tabular}{|c|c|c|c|c|c|c|c|c|}
\hline \multirow{2}{*}{$\begin{array}{c}\text { Investment } \\
\text { Objective }\end{array}$} & \multirow{2}{*}{$\begin{array}{c}\text { Level of } \\
\text { Education }\end{array}$} & \multicolumn{6}{|c|}{ Rank } & \multirow{2}{*}{ Total } \\
\hline & & 1 & 2 & 3 & 4 & 5 & 6 & \\
\hline \multirow{5}{*}{$\begin{array}{c}\text { Tax } \\
\text { Benefit }\end{array}$} & High School & 0 & 1 & 8 & 5 & 18 & 8 & 40 \\
\hline & Percent & $0.0 \%$ & $2.5 \%$ & $20.0 \%$ & $12.5 \%$ & $45.0 \%$ & $20.0 \%$ & $100.0 \%$ \\
\hline & $\begin{array}{l}\text { Higher } \\
\text { Education }\end{array}$ & 1 & 11 & 8 & 16 & 32 & 17 & 85 \\
\hline & Percent & $1.2 \%$ & $12.9 \%$ & $9.4 \%$ & $18.8 \%$ & $37.6 \%$ & $20.0 \%$ & $100.0 \%$ \\
\hline & Total & $\begin{array}{c}1 \\
08 \%\end{array}$ & $\begin{array}{c}12 \\
96 \%\end{array}$ & $\begin{array}{c}16 \\
128 \%\end{array}$ & $\begin{array}{c}21 \\
168 \%\end{array}$ & $\begin{array}{c}50 \\
400^{\circ}\end{array}$ & $\begin{array}{c}25 \\
200^{\circ}\end{array}$ & $\begin{array}{c}125 \\
1000^{\circ}\end{array}$ \\
\hline
\end{tabular}

Source: SPSS output processed results.

Regardless of the investors' levels of education, both groups do not consider tax benefit as a priority objective of investment. As mentioned above, 10\% of personal on stock gain does not give an excellent contribution to their wealth accumulation.

Table 21

\section{Level of Education and Liquidity}

\begin{tabular}{|c|c|c|c|c|c|c|c|c|}
\hline \multirow{2}{*}{$\begin{array}{c}\text { Investment } \\
\text { Objective }\end{array}$} & \multirow{2}{*}{$\begin{array}{c}\text { Level of } \\
\text { Education }\end{array}$} & \multicolumn{6}{|c|}{ Rank } & \multirow{2}{*}{ Total } \\
\hline & & 1 & 2 & 3 & 4 & 5 & 6 & \\
\hline \multirow{7}{*}{ Liquidity } & High School & 1 & 1 & 2 & 18 & 14 & 4 & 40 \\
\hline & Percent & $2.5 \%$ & $2.5 \%$ & $5.0 \%$ & $45.0 \%$ & $35.0 \%$ & $10.0 \%$ & $100.0 \%$ \\
\hline & Higher & 1 & 1 & 12 & 22 & 22 & 27 & 85 \\
\hline & Education & & & & & & & \\
\hline & Percent & $1.2 \%$ & $1.2 \%$ & $14.1 \%$ & $25.9 \%$ & $25.9 \%$ & $31.8 \%$ & $100.0 \%$ \\
\hline & Total & 2 & 2 & 14 & 40 & 36 & 31 & 125 \\
\hline & Percent & $1.6 \%$ & $1.6 \%$ & $11.2 \%$ & $32.0 \%$ & $28.8 \%$ & $24.8 \%$ & $100.0 \%$ \\
\hline
\end{tabular}

Source: SPSS output processed results.

High school level of education investors places liquidity as the fourth rank of investment objective. Moreover, the higher education level of investors put liquidity as the last priority. It seems both of group do not need to sell or buy the stocks in a very short-term. They tend to observe the market before buying and selling stocks. This is a reason for not considering liquidity as an essential investment goal.

Insert Table 22 here.

Based on the above table, it can be seen that the demographic factor "title" significantly relate to the investment objectives of the safety of principal, capital growth, 
quick returns, and liquidity. Investors with higher education tend to absorb the information and apply it to their behavior and everyday lifestyle. This study is in line with research conducted by Bhandari and Deaves (2006) who found that the higher the education level, the higher tolerance to risk by these investors.

Table 22

Chi-Square Test: Level of Education and Objectives of Investment

\begin{tabular}{lccc}
\hline \multicolumn{1}{c}{ Objective } & Value & Df & Asymp. Sig (2-sided) \\
\hline Safety of Principal & $43.996^{\mathrm{a}}$ & 5 & .000 \\
Regular Income & $12.051^{\mathrm{a}}$ & 5 & .886 \\
Capital Growth & $17.161^{\mathrm{a}}$ & 5 & .004 \\
Quick Returns & $16.063^{\mathrm{a}}$ & 5 & .007 \\
Tax Benefit & $6.957^{\mathrm{a}}$ & 5 & .224 \\
Liquidity & $11.702^{\mathrm{a}}$ & 5 & .039 \\
\hline
\end{tabular}

Source: SPSS output processed results.

In contrast, regular income and tax benefit are not significantly associated with the level of education. The reason is that the level of education is not solely referenced for investors in making an investment decision. Every individual investor has a different preference for risks.Investors who have a high education level is not necessarily willing to take high risks in investing or vice versa. According to Darmadji and Fakhruddin (2012), earnings regular fixed income is a preferred strategy because it is profitable for individual investors. Investors should commit to monitor their investments carefully to avoid significant losses. However, not all investors are afraid of significant losses because some risk taker investors expecthigher profits than risk-averse investors.

\subsection{Employment and Objectives of investment}

Table 23

Employment and Principal of Safety

\begin{tabular}{|c|c|c|c|c|c|c|c|c|}
\hline \multirow{2}{*}{$\begin{array}{c}\text { Investment } \\
\text { Objective }\end{array}$} & \multirow{2}{*}{ Employment } & \multicolumn{6}{|c|}{ Rank } & \multirow{2}{*}{ Total } \\
\hline & & 1 & 2 & 3 & 4 & 5 & 6 & \\
\hline \multirow{8}{*}{$\begin{array}{l}\text { Safety of } \\
\text { Principal }\end{array}$} & Employee & 28 & 1 & 0 & 1 & 1 & 23 & 54 \\
\hline & Percent & $51.9 \%$ & $1.9 \%$ & $0.0 \%$ & $1.9 \%$ & $1.9 \%$ & $42.6 \%$ & $100.0 \%$ \\
\hline & $\begin{array}{l}\text { Professional } \\
\text { Percent }\end{array}$ & $\begin{array}{c}16 \\
76.2 \%\end{array}$ & $\begin{array}{c}1 \\
4.8 \%\end{array}$ & $\begin{array}{c}1 \\
4.8 \%\end{array}$ & $\begin{array}{c}0 \\
0.0 \%\end{array}$ & $\begin{array}{c}0 \\
0.0 \%\end{array}$ & $\begin{array}{c}3 \\
14.3 \%\end{array}$ & $\begin{array}{c}21 \\
100.0 \%\end{array}$ \\
\hline & $\begin{array}{l}\text { Entrepreneur } \\
\text { Percent }\end{array}$ & $\begin{array}{c}16 \\
64.0 \%\end{array}$ & $\begin{array}{c}0 \\
0.0 \%\end{array}$ & $\begin{array}{c}0 \\
0.0 \%\end{array}$ & $\begin{array}{c}0 \\
0.0 \%\end{array}$ & $\begin{array}{c}3 \\
12.0 \%\end{array}$ & $\begin{array}{c}6 \\
2.4 \%\end{array}$ & $\begin{array}{c}25 \\
100.0 \%\end{array}$ \\
\hline & $\begin{array}{l}\text { Retired } \\
\text { Percent }\end{array}$ & $\begin{array}{c}4 \\
50.0 \%\end{array}$ & $\begin{array}{c}0 \\
0.0 \%\end{array}$ & $\begin{array}{c}1 \\
12.5 \%\end{array}$ & $\begin{array}{c}0 \\
0.0 \%\end{array}$ & $\begin{array}{c}1 \\
12.5 \%\end{array}$ & $\begin{array}{c}2 \\
25.0 \%\end{array}$ & $\begin{array}{c}8 \\
100.0 \%\end{array}$ \\
\hline & $\begin{array}{l}\text { Household } \\
\text { Percent }\end{array}$ & $\begin{array}{c}4 \\
100.0 \%\end{array}$ & $\begin{array}{c}0 \\
0.0 \%\end{array}$ & $\begin{array}{c}0 \\
0.0 \%\end{array}$ & $\begin{array}{c}0 \\
0.0 \%\end{array}$ & $\begin{array}{c}0 \\
0.0 \%\end{array}$ & $\begin{array}{c}0 \\
0.0 \%\end{array}$ & $\begin{array}{c}4 \\
100.0 \%\end{array}$ \\
\hline & $\begin{array}{l}\text { College } \\
\text { Student } \\
\text { Percent }\end{array}$ & $\begin{array}{c}8 \\
61.5 \%\end{array}$ & $\begin{array}{c}0 \\
0.0 \%\end{array}$ & $\begin{array}{c}0 \\
0.0 \%\end{array}$ & $\begin{array}{c}0 \\
0.0 \%\end{array}$ & $\begin{array}{c}0 \\
0.0 \%\end{array}$ & $\begin{array}{c}5 \\
38.5 \%\end{array}$ & $\begin{array}{c}13 \\
100.0 \%\end{array}$ \\
\hline & $\begin{array}{l}\text { Total } \\
\text { Percent }\end{array}$ & $\begin{array}{c}76 \\
60.8 \%\end{array}$ & $\begin{array}{c}2 \\
1.6 \%\end{array}$ & $\begin{array}{c}2 \\
1.6 \%\end{array}$ & $\begin{array}{c}1 \\
0.8 \%\end{array}$ & $\begin{array}{c}5 \\
4.0 \%\end{array}$ & $\begin{array}{c}39 \\
31.2 \%\end{array}$ & $\begin{array}{c}125 \\
100.0 \%\end{array}$ \\
\hline
\end{tabular}

Source: SPSS output processed results.

Regardless of work categories, the majority of the respondents prefer the safety of principal as the first rank investment objective. Based on the results from the above table, a high percentage is shown by each category of work, namely employee $(51.9 \%)$, professional investors $(76.2 \%)$, entrepreneur $(64.0 \%)$, pensioners $(50 \%)$, household 
$(100 \%)$, and college students (61.5\%). The individual investors show a risk-averse orconservative behavior as they are reluctant to take a risk in investment or tend to avoid risk. Therefore, most individual investors choose the Safety of Principal as a primary investment objective. The above finding is supported by Cahyadi (2010) who states that investors who work as employees, professionals, self-employed, retired, household, and others (college students) tend to chooseinvestment objectives that have a level of risk that is not too high.

\section{Table 24}

\section{Employment and Regular Income}

\begin{tabular}{|c|c|c|c|c|c|c|c|c|}
\hline \multirow{2}{*}{$\begin{array}{c}\text { Investment } \\
\text { Objective }\end{array}$} & \multirow{2}{*}{ Employment } & \multicolumn{6}{|c|}{ Rank } & \multirow{2}{*}{ Total } \\
\hline & & 1 & 2 & 3 & 4 & 5 & 6 & \\
\hline \multirow{14}{*}{$\begin{array}{l}\text { Regular } \\
\text { Income }\end{array}$} & Employee & 0 & 19 & 17 & 10 & 6 & 2 & 54 \\
\hline & Percent & $0.0 \%$ & $35.2 \%$ & $31.5 \%$ & $18.5 \%$ & $11.1 \%$ & $3.7 \%$ & $100.0 \%$ \\
\hline & Professional & 0 & 7 & 7 & 6 & 0 & 1 & 21 \\
\hline & Percent & $0.0 \%$ & $33.3 \%$ & $33.3 \%$ & $28.6 \%$ & $0.0 \%$ & $4.8 \%$ & $100.0 \%$ \\
\hline & Entrepreneur & 1 & 5 & 11 & 6 & 1 & 1 & 25 \\
\hline & Percent & $4.0 \%$ & $20.0 \%$ & $44.0 \%$ & $24.0 \%$ & $4.0 \%$ & $4.0 \%$ & $100.0 \%$ \\
\hline & Retired & 0 & 2 & 2 & 3 & 1 & 0 & 8 \\
\hline & Percent & $0.0 \%$ & $25.0 \%$ & $25.0 \%$ & $37.5 \%$ & $25.0 \%$ & $0.0 \%$ & $100.0 \%$ \\
\hline & Household & 0 & 1 & 1 & 1 & 1 & 0 & 4 \\
\hline & Percent & $0.0 \%$ & $25.0 \%$ & $25.0 \%$ & $25.0 \%$ & $25.0 \%$ & $0.0 \%$ & $0.0 \%$ \\
\hline & College & 2 & 4 & 4 & 2 & 1 & 0 & 13 \\
\hline & $\begin{array}{l}\text { Student } \\
\text { Percent }\end{array}$ & $15.4 \%$ & $30.8 \%$ & $30.8 \%$ & $15.4 \%$ & $7.7 \%$ & $0.0 \%$ & $100.0 \%$ \\
\hline & Total & 3 & 38 & 42 & 28 & 10 & 4 & 125 \\
\hline & Percent & $2.4 \%$ & $30.4 \%$ & $33.6 \%$ & $22.4 \%$ & $8.0 \%$ & $3.2 \%$ & $100.0 \%$ \\
\hline
\end{tabular}

Source: SPSS output processed results.

All group of employment investors' places regular income as second and third rank, except retirement group investors. They do not make a regular income as necessary as the other groups, i.e. fourth rank. It is supposed that retirement investors have regular incomes from other resources. The income from capital market is as additional income for them, but they are aggressive enough in capital market trading. They pursue higher income for fulfilling their needs. The rest of the groups positions the regular income as the second important objective. As suggested by Barnewall (1987), that the groups of professionals, such as a lawyer, medical doctor, firm executives, are risk-averse investors. The typical investors pursue regular income as safety income.

Table 25 shows that only employee positions capital growth as the first rank of investment's objective. The other groups place the objective as the second rank. Employees pursue a capital growth of their investment to prepare their retirement period. They might not spend the income from the capital market now since they already earn income from their working place. Meanwhile, the other groups of investors seek capital growth as the second important of investment objective. They might not be long-term investors who will keep the stocks for long-time. Some investors have commitments to invest their money for capital growth. 
Table 25

Employment and Capital Growth

\begin{tabular}{|c|c|c|c|c|c|c|c|c|}
\hline \multirow{2}{*}{$\begin{array}{c}\text { Investment } \\
\text { Objective }\end{array}$} & \multirow{2}{*}{ Employment } & \multicolumn{6}{|c|}{ Rank } & \multirow{2}{*}{ Total } \\
\hline & & 1 & 2 & 3 & 4 & 5 & 6 & \\
\hline \multirow{14}{*}{$\begin{array}{l}\text { Capital } \\
\text { Growth }\end{array}$} & Employee & 20 & 14 & 10 & 6 & 2 & 2 & 54 \\
\hline & Percent & $37.0 \%$ & $25.9 \%$ & $18.5 \%$ & $11.1 \%$ & $3.7 \%$ & $3.7 \%$ & $100.0 \%$ \\
\hline & Professional & 0 & 5 & 4 & 2 & 5 & 5 & 21 \\
\hline & Percent & $0.0 \%$ & $23.8 \%$ & $19.0 \%$ & $9.5 \%$ & $23.8 \%$ & $23.8 \%$ & $100.0 \%$ \\
\hline & Entrepreneur & 1 & 12 & 5 & 5 & 2 & 0 & 25 \\
\hline & Percent & $4.0 \%$ & $48.0 \%$ & $20.0 \%$ & $20.0 \%$ & $8.0 \%$ & $0.0 \%$ & $100.0 \%$ \\
\hline & Retired & 0 & 5 & 1 & 0 & 1 & 1 & 8 \\
\hline & Percent & $0.0 \%$ & $62.5 \%$ & $12.5 \%$ & $0.0 \%$ & $12.5 \%$ & $12.5 \%$ & $100.0 \%$ \\
\hline & Household & 0 & 1 & 1 & 0 & 1 & 1 & 4 \\
\hline & Percent & $0.0 \%$ & $25.0 \%$ & $25.0 \%$ & $0.0 \%$ & $25.0 \%$ & $25.0 \%$ & $0.0 \%$ \\
\hline & College & 0 & 7 & 4 & 1 & 1 & 0 & 13 \\
\hline & $\begin{array}{l}\text { Student } \\
\text { Percent }\end{array}$ & $0.0 \%$ & $53.8 \%$ & $30.8 \%$ & $7.7 \%$ & $7.7 \%$ & $0.0 \%$ & $100.0 \%$ \\
\hline & Total & 21 & 44 & 25 & 14 & 12 & 9 & 125 \\
\hline & Percent & $16.8 \%$ & $35.2 \%$ & $20.0 \%$ & $11.2 \%$ & $9.6 \%$ & $7.2 \%$ & $100.0 \%$ \\
\hline
\end{tabular}

Source: SPSS output processed results.

Table 26

Employment and Quick Returns

\begin{tabular}{|c|c|c|c|c|c|c|c|c|}
\hline \multirow{2}{*}{$\begin{array}{l}\text { Investment } \\
\text { Objective }\end{array}$} & \multirow{2}{*}{ Tax Benefit } & \multicolumn{6}{|c|}{ Rank } & \multirow{2}{*}{ Total } \\
\hline & & 1 & 2 & 3 & 4 & 5 & 6 & \\
\hline \multirow{14}{*}{$\begin{array}{l}\text { Quick } \\
\text { Return }\end{array}$} & Employee & 9 & 14 & 15 & 7 & 3 & 6 & 54 \\
\hline & Percent & $16.7 \%$ & $25.9 \%$ & $27.8 \%$ & $13.0 \%$ & $5.6 \%$ & $11.1 \%$ & $100.0 \%$ \\
\hline & Professional & 5 & 4 & 3 & 4 & 2 & 3 & 21 \\
\hline & Percent & $23.8 \%$ & $19.0 \%$ & $14.3 \%$ & $19.0 \%$ & $9.5 \%$ & $14.3 \%$ & $100.0 \%$ \\
\hline & Entrepreneur & 7 & 6 & 5 & 3 & 3 & 1 & 25 \\
\hline & Percent & $28.0 \%$ & $24.0 \%$ & $20.0 \%$ & $12.0 \%$ & $12.0 \%$ & $4.0 \%$ & $100.0 \%$ \\
\hline & Retired & 4 & 0 & 2 & 1 & 0 & 1 & 8 \\
\hline & Percent & $50.0 \%$ & $0.0 \%$ & $25.0 \%$ & $12.5 \%$ & $0.0 \%$ & $12.5 \%$ & $100.0 \%$ \\
\hline & Household & 0 & 0 & 1 & 2 & 1 & 0 & 4 \\
\hline & Percent & $0.0 \%$ & $0.0 \%$ & $25.0 \%$ & $50.0 \%$ & $25.0 \%$ & $0.0 \%$ & $0.0 \%$ \\
\hline & College & 2 & 1 & 2 & 2 & 2 & 4 & 13 \\
\hline & $\begin{array}{l}\text { Student } \\
\text { Percent }\end{array}$ & $15.4 \%$ & $7.7 \%$ & $15.4 \%$ & $15.4 \%$ & $15.4 \%$ & $30.8 \%$ & $100.0 \%$ \\
\hline & Total & 27 & 25 & 28 & 19 & 11 & 15 & 125 \\
\hline & Percent & $21.6 \%$ & $20.0 \%$ & $22.4 \%$ & $15.2 \%$ & $8.8 \%$ & $12.0 \%$ & $100.0 \%$ \\
\hline
\end{tabular}

Source: SPSS output processed results.

From the table above, we can say that professionals and entrepreneur group of investors rank the quick returns as the priority of their investment objectives. It is supposed that professionals and entrepreneur group of investors invest their money in the capital market free cash flow, and they want to spend the money for entertainments. Meanwhile, the employee places quick returns as the third priority. It is consistent with the previous result. The employees concern more in capital growth for accumulating their wealth, with the purpose of retirement preparation. Barber and Odean (2001) argued that people's carrier determines the decision of the investment sector, real sector, or capital market. The high salary people tend to invest their money in the capital market for getting free cash flow. 
Table 27

Employment and Tax Benefit

\begin{tabular}{|c|c|c|c|c|c|c|c|c|}
\hline \multirow{2}{*}{$\begin{array}{c}\text { Investment } \\
\text { Objective }\end{array}$} & \multirow{2}{*}{ Tax Benefit } & \multicolumn{6}{|c|}{ Rank } & \multirow{2}{*}{ Total } \\
\hline & & 1 & 2 & 3 & 4 & 5 & 6 & \\
\hline \multirow{14}{*}{$\begin{array}{c}\text { Tax } \\
\text { Benefit }\end{array}$} & Employee & 0 & 3 & 5 & 13 & 21 & 12 & 54 \\
\hline & Percent & $0.0 \%$ & $5.6 \%$ & $9.3 \%$ & $24.1 \%$ & $38.9 \%$ & $22.2 \%$ & $100.0 \%$ \\
\hline & Professional & 1 & 4 & 3 & 3 & 7 & 3 & 21 \\
\hline & Percent & $4.8 \%$ & $19.0 \%$ & $14.3 \%$ & $14.3 \%$ & $33.3 \%$ & 14.3 & $100.0 \%$ \\
\hline & Entrepreneur & 0 & 2 & 2 & 2 & 12 & 7 & 25 \\
\hline & Percent & $0.0 \%$ & $8.0 \%$ & $8.0 \%$ & $8.0 \%$ & $48.0 \%$ & 28.0 & $100.0 \%$ \\
\hline & Retired & 0 & 1 & 2 & 0 & 4 & 1 & 8 \\
\hline & Percent & $0.0 \%$ & $12.5 \%$ & $25.0 \%$ & $0.0 \%$ & $50.0 \%$ & $12.5 \%$ & $100.0 \%$ \\
\hline & Household & 0 & 2 & 0 & 0 & 1 & 1 & 4 \\
\hline & Percent & $0.0 \%$ & $50.0 \%$ & $0.0 \%$ & $0.0 \%$ & $25.0 \%$ & $25.0 \%$ & $0.0 \%$ \\
\hline & College & 0 & 0 & 4 & 3 & 5 & 1 & 13 \\
\hline & $\begin{array}{l}\text { Student } \\
\text { Percent }\end{array}$ & $0.0 \%$ & $0.0 \%$ & $30.8 \%$ & $23.1 \%$ & $38.5 \%$ & $7.7 \%$ & $100.0 \%$ \\
\hline & Total & 1 & 12 & 16 & 21 & 50 & 25 & 125 \\
\hline & Percent & $0.8 \%$ & $9.6 \%$ & $12.8 \%$ & $16.8 \%$ & $40.0 \%$ & $20.0 \%$ & $100.0 \%$ \\
\hline
\end{tabular}

Source: SPSS output processed results.

Table 27 proves that most of the group of investors are the least concern to the tax benefit. The phenomenon does not change with the other socio-demographic factors. Nevertheless, the household group of investors put the tax benefit as the second important objective. It suggests that the household does not earn their income. Ten percent of the final tax is still considered giving them free cash flow. Moreover, the households are dependent, too emotional, and lack of self-confident, therefore a small additional cash flow will make them satisfied.

Table 28

Employment and Liquidity

\begin{tabular}{|c|c|c|c|c|c|c|c|c|}
\hline \multirow{2}{*}{$\begin{array}{c}\text { Investment } \\
\text { Objective }\end{array}$} & \multirow{2}{*}{ Employment } & \multicolumn{6}{|c|}{ Rank } & \multirow{2}{*}{ Total } \\
\hline & & 1 & 2 & 3 & 4 & 5 & 6 & \\
\hline \multirow{13}{*}{ Liquidity } & Employee & 0 & 1 & 7 & 17 & 21 & 8 & 54 \\
\hline & Percent & $0.0 \%$ & $1.9 \%$ & $13.0 \%$ & $31.5 \%$ & $38.9 \%$ & $14.8 \%$ & $100.0 \%$ \\
\hline & Professional & 1 & 0 & 3 & 6 & 6 & 5 & 21 \\
\hline & Percent & $4.8 \%$ & $0.0 \%$ & $14.3 \%$ & $28.9 \%$ & $28.9 \%$ & $23.8 \%$ & $100.0 \%$ \\
\hline & Entrepreneur & 0 & 0 & 2 & 9 & 4 & 10 & 25 \\
\hline & Percent & $0.0 \%$ & $0.0 \%$ & $8.0 \%$ & $36.0 \%$ & $16.0 \%$ & $40.0 \%$ & $100.0 \%$ \\
\hline & Retired & 0 & 0 & 1 & 4 & 1 & 2 & 8 \\
\hline & Percent & $0.0 \%$ & $0.0 \%$ & $12.5 \%$ & $50.0 \%$ & $12.5 \%$ & $25.0 \%$ & $100.0 \%$ \\
\hline & Household & 0 & 0 & 1 & 1 & 0 & 2 & 4 \\
\hline & Percent & $0.0 \%$ & $0.0 \%$ & $25.0 \%$ & $25.0 \%$ & $0.0 \%$ & $50.0 \%$ & $100.0 \%$ \\
\hline & $\begin{array}{l}\text { College } \\
\text { Student } \\
\text { Percent }\end{array}$ & $\begin{array}{c}1 \\
7.7 \%\end{array}$ & $\begin{array}{c}1 \\
7.7 \%\end{array}$ & $\begin{array}{c}0 \\
0.0 \%\end{array}$ & $\begin{array}{c}3 \\
23.1 \%\end{array}$ & $\begin{array}{c}4 \\
30.8 \%\end{array}$ & $\begin{array}{c}4 \\
30.8 \%\end{array}$ & $\begin{array}{c}13 \\
100.0 \%\end{array}$ \\
\hline & Total & 2 & 2 & 14 & 40 & 36 & 31 & 125 \\
\hline & Percent & $1.6 \%$ & $1.6 \%$ & $11.2 \%$ & $32.0 \%$ & $28.8 \%$ & $24.8 \%$ & $100.0 \%$ \\
\hline
\end{tabular}

Source: SPSS output processed results.

From the above table, the group of professional and retired people placed the liquidity as the fourth rank. It implies that they trade in the capital market for obtaining free cash flow. This is the reason why they do not concern on liquidity. 
Moreover, people with professional work background, such as lawyer and doctor are risk-averse investors. The rest of the group too put liquidity as the fifth and sixth priority of their investment objectives. In the case of a household, they are lack of knowledge and skill in the capital market. The only concern for them is that the safety of their investment principal.

Table 29

Chi-Square Test: Employment and Objectives of Investment

\begin{tabular}{lccc}
\hline \multicolumn{1}{c}{ Objective } & Value & Df & Asymp. Sig (2-sided) \\
\hline Safety of Principal & $28.716^{\mathrm{a}}$ & 25 & .276 \\
Regular Income & $21.527^{\mathrm{a}}$ & 25 & .663 \\
Capital Growth & $55.367^{\mathrm{a}}$ & 25 & .000 \\
Quick Returns & $24.478^{\mathrm{a}}$ & 25 & .492 \\
Tax Benefit & $30.619^{\mathrm{a}}$ & 25 & .202 \\
Liquidity & $24.814^{\mathrm{a}}$ & 25 & .473 \\
\hline
\end{tabular}

Source: SPSS output processed results.

Based on the above table, it can be seen that the demographic factor "work" is significantly related to the investment objective of capital growth, this is due to capital growth has the advantage of high returns on investments. So investors get their wealth growth through capital growth's investment return for value appreciation or other benefits of their investments. The commitment of funds of investors in a period to get revenues Capital Growth is expected in the future as compensation for each unit invested.

Meanwhile, work does not have any significant relationship to the investment objectives of safety of principal, regular income, quick returns, tax benefit, and liquidity. Regardless of any work committed by the investors, they tend to be risk-averse where they want to avoid risk but do expect to have some return. However, some investors arecourageous in taking a risk in investing where they choose capital growth as an investment objective because the investors feel that they have enough funds to invest or so they do not hesitate in taking a high risk in investing.

\subsection{Marital Status and Objective of Investment}

Table 30

Marital Status and Safety of Principal

\begin{tabular}{|c|c|c|c|c|c|c|c|c|}
\hline \multirow{2}{*}{$\begin{array}{c}\text { Investment } \\
\text { Objective }\end{array}$} & \multirow{2}{*}{$\begin{array}{c}\text { Marital } \\
\text { Status }\end{array}$} & \multicolumn{6}{|c|}{ Rank } & \multirow{2}{*}{ Total } \\
\hline & & 1 & 2 & 3 & 4 & 5 & 6 & \\
\hline \multirow{6}{*}{$\begin{array}{l}\text { Safety of } \\
\text { Principal }\end{array}$} & Single & 19 & 1 & 2 & 1 & 4 & 36 & 63 \\
\hline & Percent & $30.2 \%$ & $1.6 \%$ & $3.2 \%$ & $1.6 \%$ & $6.3 \%$ & $57.1 \%$ & $100.0 \%$ \\
\hline & Married & 57 & 1 & 0 & 0 & 1 & 3 & 62 \\
\hline & Percent & $91.9 \%$ & $1.6 \%$ & $0.0 \%$ & $0.0 \%$ & $1.6 \%$ & $4.8 \%$ & $100.0 \%$ \\
\hline & Total & 76 & 2 & 2 & 1 & 5 & 39 & 125 \\
\hline & Percent & $60.8 \%$ & $1.6 \%$ & $1.6 \%$ & $0.8 \%$ & $4.0 \%$ & $31.2 \%$ & $100.0 \%$ \\
\hline
\end{tabular}

Source: SPSS output processed results.

From the above table, the most significant percentage $(57.1 \%)$ of single investors choose Safety of Principal as the lowest rank in the rank of 6, which indicates this investment objective is not their primary concern. In contrast, most married investors $(91.9 \%)$ make "safety of principal" a priority in investment objectives. Single investors tend to invest their funds in riskier assets than investors who are married (Lutfi, 2010). This explains that married investors are the type of investors who avoid risk (riskaverse) because they put more priority to the household needs first. 
Table 31

Marital Status and Regular Income

\begin{tabular}{|c|c|c|c|c|c|c|c|c|}
\hline \multirow{2}{*}{$\begin{array}{c}\text { Investment } \\
\text { Objective }\end{array}$} & \multirow{2}{*}{$\begin{array}{c}\text { Marital } \\
\text { Status } \\
\end{array}$} & \multicolumn{6}{|c|}{ Rank } & \multirow{2}{*}{ Total } \\
\hline & & 1 & 2 & 3 & 4 & 5 & 6 & \\
\hline \multirow{6}{*}{$\begin{array}{l}\text { Regular } \\
\text { Income }\end{array}$} & Single & 3 & 14 & 22 & 17 & 6 & 1 & 63 \\
\hline & Percent & $4.8 \%$ & $22.2 \%$ & $34.9 \%$ & $27.0 \%$ & $9.5 \%$ & $1.6 \%$ & $100.0 \%$ \\
\hline & Married & 0 & 24 & 20 & 11 & 4 & 3 & 62 \\
\hline & Percent & $0.0 \%$ & $38.7 \%$ & $32.3 \%$ & $17.7 \%$ & $6.5 \%$ & $4.8 \%$ & $100.0 \%$ \\
\hline & Total & 3 & 38 & 42 & 28 & 10 & 4 & 125 \\
\hline & Percent & $2.4 \%$ & $30.4 \%$ & $33.6 \%$ & $22.4 \%$ & $8.0 \%$ & $3.2 \%$ & $100.0 \%$ \\
\hline
\end{tabular}

Source: SPSS output processed results.

From the table above, we can conclude that a group of non-married investors does not rank regular income as an important goal. They supposed to receive enough money for their basic needs. However, the income from capital market is as additional money for entertainment spending. On the other hand, the group of married investors positions regular income as the second crucial goal. As married people, they have higher basic needs than non-married people do. Consequently, they have to acquire additional income from other resources to fulfill their needs. Married investors provide more funds to invest compared to the non-married group of investors. Furthermore, with the children come along into their life, they demand more income than nonmarried investors.

Table 32

Marital Status and Capital Growth

\begin{tabular}{|c|c|c|c|c|c|c|c|c|}
\hline \multirow{2}{*}{$\begin{array}{c}\text { Investment } \\
\text { Objective }\end{array}$} & \multirow{2}{*}{$\begin{array}{c}\text { Marital } \\
\text { Status }\end{array}$} & \multicolumn{6}{|c|}{ Rank } & \multirow{2}{*}{ Total } \\
\hline & & 1 & 2 & 3 & 4 & 5 & 6 & \\
\hline \multirow{6}{*}{$\begin{array}{l}\text { Capital } \\
\text { Growth }\end{array}$} & Single & 18 & 27 & 10 & 5 & 3 & 0 & 63 \\
\hline & Percent & $28.6 \%$ & $42.9 \%$ & $15.9 \%$ & $7.9 \%$ & $4.8 \%$ & $0.0 \%$ & $100.0 \%$ \\
\hline & Married & 3 & 17 & 15 & 9 & 9 & 9 & 62 \\
\hline & Percent & $4.8 \%$ & $27.4 \%$ & $24.2 \%$ & $14.5 \%$ & $14.5 \%$ & $14.5 \%$ & $100.0 \%$ \\
\hline & Total & 21 & 44 & 25 & 14 & 12 & 9 & 125 \\
\hline & Percent & $16.8 \%$ & $35.2 \%$ & $20.0 \%$ & $11.2 \%$ & $9.6 \%$ & $7.2 \%$ & $100.0 \%$ \\
\hline
\end{tabular}

Source: SPSS output processed results.

Both groups see that capital growth is an essential goal for them. They put the objective as a second important goal. Capital growth is crucial for wealth accumulation. Sudiyatno and Suroso (2010) argued that an increase in capital growth is one of the achievements of the firms, which are in line with the investors' demand.

Table 33

Marital Status and Quick Returns

\begin{tabular}{clccccccc}
\hline Investment & Marital & \multicolumn{8}{c}{ Rank } & \multirow{2}{*}{ Objective } \\
\cline { 2 - 8 } & Status & $\mathbf{1}$ & $\mathbf{2}$ & $\mathbf{3}$ & $\mathbf{4}$ & $\mathbf{5}$ & $\mathbf{6}$ & \\
\hline \multirow{4}{*}{$\begin{array}{c}\text { Quick } \\
\text { Returns }\end{array}$} & Single & 21 & 15 & 12 & 4 & 5 & 6 & 63 \\
& Percent & $33.3 \%$ & $23.8 \%$ & $19.0 \%$ & $6.3 \%$ & $7.9 \%$ & $9.5 \%$ & $100.0 \%$ \\
\cline { 2 - 8 } & Married & 6 & 10 & 16 & 15 & 6 & 9 & 62 \\
& Percent & $9.7 \%$ & $16.1 \%$ & $25.8 \%$ & $24.2 \%$ & $9.7 \%$ & $14.5 \%$ & $100.0 \%$ \\
\cline { 2 - 8 } & Total & 27 & 25 & 28 & 19 & 11 & 15 & 125 \\
& Percent & $21.6 \%$ & $20.0 \%$ & $22.4 \%$ & $15.2 \%$ & $8.8 \%$ & $12.0 \%$ & $100.0 \%$ \\
\hline
\end{tabular}

Source: SPSS output processed results. 
It is not surprising that the group of non-married investors put quick returns as their first goal. As mentioned above, they demand an additional income for entertainment spending. Quick returns satisfy their needs. Meanwhile, the group of married investors places quick returns as the third rank goal. It supposed that married investors are more conservative in investing their money. They have a family who depends on them financially. Lutfi (2010) stated that married investors are typically riskaverse investors.

Table 34

Marital Status and Tax Benefit

\begin{tabular}{|c|c|c|c|c|c|c|c|c|}
\hline \multirow{2}{*}{$\begin{array}{c}\text { Investment } \\
\text { Objective }\end{array}$} & \multirow{2}{*}{$\begin{array}{c}\text { Marital } \\
\text { Status }\end{array}$} & \multicolumn{6}{|c|}{ Rank } & \multirow{2}{*}{ Total } \\
\hline & & 1 & 2 & 3 & 4 & 5 & 6 & \\
\hline \multirow{6}{*}{$\begin{array}{c}\text { Tax } \\
\text { Benefit }\end{array}$} & Single & 0 & 5 & 10 & 12 & 27 & 9 & 63 \\
\hline & Percent & $0.0 \%$ & $7.9 \%$ & $15.9 \%$ & $19.0 \%$ & $42.9 \%$ & $14.3 \%$ & $100.0 \%$ \\
\hline & Married & 1 & 7 & 6 & 9 & 23 & 16 & 62 \\
\hline & Percent & $1.6 \%$ & $11.3 \%$ & $9.7 \%$ & $14.5 \%$ & $37.1 \%$ & $25.8 \%$ & $100.0 \%$ \\
\hline & Total & 1 & 12 & 16 & 21 & 50 & 25 & 125 \\
\hline & Percent & $0.8 \%$ & $9.6 \%$ & $12.8 \%$ & $16.8 \%$ & $40.0 \%$ & $20.0 \%$ & $100.0 \%$ \\
\hline
\end{tabular}

Source: SPSS output processed results.

Again, both groups of investors do not concern tax benefit as their primary investment goal. The reason is that ten percent of personal tax is quite high enough to reduce their income.

Table 35

Marital Status and Liquidity

\begin{tabular}{|c|c|c|c|c|c|c|c|c|}
\hline \multirow{2}{*}{$\begin{array}{c}\text { Investment } \\
\text { Objective }\end{array}$} & \multirow{2}{*}{$\begin{array}{c}\text { Marital } \\
\text { Status }\end{array}$} & \multicolumn{6}{|c|}{ Rank } & \multirow{2}{*}{ Total } \\
\hline & & 1 & 2 & 3 & 4 & 5 & 6 & \\
\hline \multirow{6}{*}{ Liquidity } & Single & 2 & 1 & 8 & 22 & 18 & 12 & 63 \\
\hline & Percent & $3.2 \%$ & $1.6 \%$ & $12.7 \%$ & $34.9 \%$ & $28.6 \%$ & $19.0 \%$ & $100.0 \%$ \\
\hline & Married & 0 & 1 & 6 & 18 & 18 & 19 & 62 \\
\hline & Percent & $0.0 \%$ & $1.6 \%$ & $9.7 \%$ & $29.0 \%$ & $29.0 \%$ & $30.6 \%$ & $100.0 \%$ \\
\hline & Total & 2 & 2 & 14 & 40 & 36 & 31 & 125 \\
\hline & Percent & $1.6 \%$ & $1.6 \%$ & $11.2 \%$ & $32.0 \%$ & $28.8 \%$ & $24.8 \%$ & $100.0 \%$ \\
\hline
\end{tabular}

Source: SPSS output processed results.

Liquidity is the least important for both investors' group. Even though nonmarried investors group demands on a quick returns investment, but they seem to be careful in buying and selling the stocks, i.e., they are not short-term investors who need to monitor the market movement most of the time.

Table 36

Chi-Square Test: Marital Status and Objectives of Investment

\begin{tabular}{lccc}
\hline \multicolumn{1}{c}{ Objective } & Value & Df & Asymp. Sig (2-sided) \\
\hline Safety of Principal & $51.718^{\mathrm{a}}$ & 5 & .000 \\
Regular Income & $8.405^{\mathrm{a}}$ & 5 & .135 \\
Capital Growth & $27.142^{\mathrm{a}}$ & 5 & .000 \\
Quick Returns & $16.957^{\mathrm{a}}$ & 5 & .005 \\
Tax Benefit & $5.034^{\mathrm{a}}$ & 5 & .412 \\
Liquidity & $4.259^{\mathrm{a}}$ & 5 & .513 \\
\hline
\end{tabular}

Source: SPSS output processed results.

Based on the above table, it can be seen that the demographic factor "marital status" is significantly related to the investment objectives of the safety of principal, capital growth, and quick returns.It may be related to this result is due to the nature of 
married investors who have responded to the family. Therefore they need to earn profits from their investments, but at the same time they also want security to the safety of principal (Gitman \& Joehnk, 2005), thus show lower risk tolerance (Grable \& Lytton, 1998). The result of this study is in line with research conducted by Rizaldy et al. (2015). Furthermore, single investors tend to invest in instruments in the capital markets, which could give quick returns or profits in the form of dividends or capital gains, in order to increase their wealth. Investors who are single or married will want a regular income, tax benefits, and liquidity because it is very profitable for individual investors where investors are committed to monitoring its investments carefully (Darmadji \& Fakhrudin, 2012).

\section{CONCLUSIONS}

This research investigates the association of demographic factors (age, gender, level of education, work, and marital status) with individual investment objectives. All the demographic factors considered in the study show a significant contribution to the investment objectives of the individual investors in Malang district. The findings suggest that the demographic factors are essential in determining the investment objectives of the individual investor. The "safety of principal" investment objective is ranked number one in the study, and all the demographic factors are associated with this investment objective except for employment categories. Investors in the study tend to be very concerned with their investment principal and are considered as risk-averse.

The results of this study can benefit both individual investors and securities firms. For individual investors, this study can be a guideline for them to make an investment decision by considering an investment objective that suits them the most. While for the securities companies, they can market their products to investors appropriately by looking into the demographic factors of the investors and indirectly know the investors' investments preference. For future research, it is recommended to expand the geographic research area by including other different regions in Indonesia. This will give a better answer to whether the findings could apply to the whole nation.

In conclusion, the investment objectives are highly associated with demographic factors. Thus, the securities companies should provide the variety of investments' products, which suit the needs of individual investors, whilethe government needs to enhance the infrastructure of the financial sector in order to increase individuals participation in the sector.

\section{REFERENCES}

Barber, B., \& Odean, T. (2001). Boys will be boys: Gender, overconfidence, and common stock investment. The Quarterly Journal of Economics, 116(1), 261-292.

Barnewall, M. (1987). Psychological characteristics of the individual investor. ICFA Continuing Education Series, 2, 62-71.

Bhandari, G., \& Deaves, R. (2006). The demographics of overconfidence. Journal of Behavioral Finance, 7(1), 5-11.

Cahyadi, S. M., (2010). The influence of demographic factors against investor behavior and type of investment. Bachelor's Thesis. STIE Perbanas, Surabaya.

Christanti, N., \& Mahastanti, L. A. (2011). Factors considering investors in investing. Journal of Theory \& Applied Management, 4(3), 37-51.

Cooper, D. R., \& Schindler, P. S. (2006). Methods of business research (9th ed., vol. 2). Jakarta: Salemba Four. 
Corrado, C. J., \& Jordan, B. D. (2000). Fundamentals of invesment analysis (4th ed.). Singapore: McGraw-Hill.

Darmadji, T., \& Fakhruddin, H. M. (2012). Capital market in Indonesia (Issue three). Jakarta: Salemba Four.

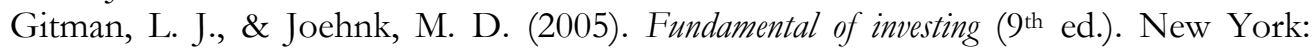
Pearson.

Grable, J. E., \& Lytton, R. H. (1998). Investor risk tolerance: Testing the efficacy of demographics as differentiating and classifying factors. Financial Counseling \& Planning, 9(1), 61-73.

Jorion, P. (2000). Risk management lessons from long-term capital management. European Financial Management, 6(3), 277-300

Kiran, D., \& Rao, U. S. (2005). Identifying investor group segments based on demographic and psychographic characteristics (pp. 1-9). $8^{\text {th }}$ Capital Markets Conference, Indian Institute of Capital Markets Paper.

Komarudin, A. (2004). Dasar-dasar manajemen investasi dan portofolio (Edisi revisi). Jakarta: PT. Rineka Cipta.

Lewellen, W. G., Lease, R. C., \& Schlarbaum, G. G. (1977). Patterns of investment strategy and behavior among individual investors. Journal of Business, 50(3), 296333.

Lutfi. (2010). The relationship between demographic factors and investment decisions in Surabaya. Journal of Economics, Business, \& Accountancy Ventura, 13(3), 213-224.

Mittal, M., \& Vyas, R. (2011). A study of psychological reasons for gemming differences in preferences for risk and investment decisions making. The IUP Journal of Behavioral Finance, 8(3), 45-50.

Nguyen, T., \& Schübler, A. (2012). Investment decisions and socio-demographic characteristics empirical evidence from Germany. International Journal of Economics \& Finance, 4(9), 1-12.

Rizaldy, T., Linawati. N., \& Memarista, G. (2015). Analisa hubungan faktor demografi, profil risiko, dan keputusan investor dalam alokasi aset. FINESTA, 3(2), 73-78.

Sunariyah. (2011). Introduction to capital market knowledge (6th ed.). Yogyakarta: College of Management Sciences.

Sudiyatno, B. \& Suroso, J. (2010). Analisis pengaruh dana pihak ketiga, Bopo, CAR dan LDR terhadap kinerja keuangan pada sektor perbankan yang go public di Bursa Efek Indonesia (BEI) periode 2005-2008. Dinamika Kenangan \& Perbankan, 2(2), 125-137.

Watson, J., \& McNaughton, M. (2007). Gender differences in risk aversion and expected retirement benefits. Financial Analyst Journal, 63(4), 52-62.

Zinkhan, G. M., \& Karande, K. W. (1990). Cultural and gender differences in risktaking behavior among America and Spanish decision makers. The Journal of Social Psychology, 131(5), 741-742. 